\title{
Cetopsorhamdia iheringi (Siluriformes, Heptapteridae): a new record for the freshwater ichthyofauna of Argentina
}

\author{
Mauricio Fabián BENITEZ¹, Guillermo Enrique TERÁN², Felipe ALONSO ${ }^{3}$, Gastón AGUILERA² \& \\ Juan Marcos MIRANDE ${ }^{2}$

\begin{abstract}
${ }^{1}$ Instituto de Biología Subtropical; UNaM-CONICET. Laboratorio de Genética Evolutiva. Félix de Azara 1552, N3300LQH- Posadas, Argentina, mauriciofbenitez@gmail.com. ${ }^{2}$ Instituto de Vertebrados, Fundación Miguel Lillo; UEL-CONICET. Miguel Lillo 251, T4000JFE - San Miguel de Tucumán, Argentina. ${ }^{3}$ Instituto de Bio y
\end{abstract} \\ Geociencias del NOA (IBIGEO-CONICET), CCT-Salta, 9 de Julio 14, 4405 Rosario de Lerma, Salta, Argentina.
}

\begin{abstract}
Cetopsorhamdia is a genus of Neotropical catfishes with a broad distribution in the main drainages of South America. Herein we report the first record of Cetopsorhamdia iheringi in Argentina and comment on the type series of the species.
\end{abstract}

Key words: Catfish, Paraná, Misiones, distribution.

Resumen: Cetpsorhamdia iheringi (Siluriformes, Heptapteridae): un nuevo registro para la ictiofauna de agua dulce de Argentina. Cetopsorhamdia es un género de bagres neotropicales con amplia distribución en las principales cuencas de Sudamérica. Aquí reportamos el primer registro de Cetopsorhamdia iheringi en la Argentina y discutimos sobre la serie tipo de la especie.

Palabras clave: Bagres, Paraná, Misiones, distribución.

\section{INTRODUCTION}

The genus Cetopsorhamdia Eigenmann \& Fisher 1916, with nine species currently considered valid (Eschmeyer et al., 2017), has a broad distribution including the main Neotropical basins: Orinoco, Amazon, and Rio de La Plata. The genus is also present in the cis-Andean Magdalena River basin, as well as coastal rivers of northeastern Brazil (Bockmann \& Guazzelli, 2003; Ferraris, 2007).

Cetopsorhamdia is diagnosed by the following combination of characters: first dorsal and pectoral-fin rays not spinous, anal-fin moderately developed, lower caudal-fin lobe longer than upper one, origin of pelvic-fin just below dorsalfin, adipose fin base three times longer than its depth, small frontal fontanel distant from the long parietal fontanel, skull covered with skin, minute occipital process, orbit without free margin, subconical head, projected snout, and absence of teeth in vomer and palatine.

The small catfish Cetopsorhamdia iheringi Schubart \& Gomes 1959 was described with specimens from Mogi-Guaçu and Camanducaia rivers. The former is a tributary of Grande River and the latter is part of the Tocantins River basin. Subsequent studies reported its presence at headwater riffles of the São Francisco River (Casatti \& Castro, 1998) as well as in many drainages of the Upper Paraná system (Pavanelli et al., 2007; da Graça \& Pavanelli, 2007; Ingenito \& Buckup, 2007; Cunico et al., 2009; Casarim et al., 2012; Cetra et al., 2012; Delariva \& da Silva, 2013). Recent expeditions to Northeastern Argentina at Paraná River basin, in Misiones, resulted in the collection of specimens identified as $C$. iheringi, that represent the first records of this species from this country. These specimens extend the species known distribution about $260 \mathrm{~km}$ southward and are the first record of Cetopsorhamdia iheringi in the Middle Paraná system.

Along with the original diagnosis of Cetopsorhamdia iheringi, Schubart and Gomez (1959) distinguished this species only from C. insidiosa and a species currently included in genus Imparfinis Eigenmann \& Norris, 1900. Herein we provide a full comparison of $C$. iheringi with all species of the genus and comment on the type series of the species. 


\section{MATERIALS AND METHODS}

Specimens of Cetopsorhamdiaiheringi (Fig. 1) were collected by electrofishing in four different tributaries of Paraná River: Tabay (26⒌'56.2'S $\left.55^{\circ} 10^{\prime} 43^{\prime \prime} \mathrm{W}\right), \quad 3$ de Mayo $\left(26^{\circ} 45^{\prime} 28,8^{\prime \prime} \mathrm{S}\right.$ $\left.54^{\circ} 55^{\prime} 26,4^{\prime \prime} \mathrm{W}\right)$, Isla (26⒊ $36^{\prime} 22.7^{\prime}$ 'S $54^{\circ} 27^{\prime} 18.4^{\prime \prime} \mathrm{W}$ ) and Uruzú $\left(25^{\circ} 51^{\prime} 20.77^{\prime}\right.$ 'S $\left.54^{\circ} 10^{\prime} 01^{\prime \prime} \mathrm{W}\right)$ streams (Fig. 2). Collected fish were euthanized by immersion in an anesthetic solution, fixed in a $4 \%$ formaldehyde solution and preserved in 70\% ethanol. All studied specimens were deposited at public ichthyological collections. Identification was performed following original descriptions (Eigenmann, 1916; Eigenmann, 1922; Schultz, 1944; Fowler, 1945; Schubart \& Gomes, 1959; Stewart, 1985), considering also data in subsequent revisions (Ruiz \& Román-Valencia, 2006; Ortega-Lara, 2012). Meristic and morphometric data were taken following Lundberg \& McDade (1986). Measurements were taken with digital caliper to the nearest $0.1 \mathrm{~mm}$. Anteriormost unbranched rays are represented by Roman numerals and branched rays by Arabic numerals. Asterisks refer to the modal number or configuration of the fin rays.

Species distributional database SpeciesLink (http://splink.cria.org.br/) was consulted to search for collecting localities of Cetopsorhamdia iheringi closer to our records and also for the most northern, southern, eastern and western distributional points of the species.

Institutional abbreviations: CI-FML (Colección ictiológica Fundación Miguel Lillo, San Miguel de Tucumán, Argentina); LGE-P (Laboratorio de Genética Evolutiva- Peces, Posadas, Argentina); IBIGEO-I (Colección Ictiológica, Instituto de Bio y Geociencias del NOA, Salta, Argentina); MZUEL (Museu de Zoologia da Universidade Estadual de Londrina, Brazil); NUP (Coleção Ictiológica do Nupélia, Maringá, Brazil); MBML (Museu de Biologia Professor Mello Leitão, Santa Teresa, Espírito Santo, Brazil); MCP (Museu de Ciências e Tecnologia, Pontifícia Universidade Católica do Rio Grande do Sul, Porto Alegre, Brazil).

\section{RESULTS}

Description and comparisons: The samplings resulted in the capture of 22 individuals of Cetopsorhamdia iheringi: 12 from Tabay, five from 3 de Mayo, one from Isla and four from Uruzú streams. Specimens of C. iheringi (Fig. 1) herein reported were characterized by a long and slender body, almost conical head, with its length 3.6-4.2 and its depth 5.7-6.7 in SL. Body depth 4.2-5.5, caudal peduncle depth 8.7-9.3, Anal-fin base 7.2-7.5, adipose fin-base 5.4-7.2, and maxillary barbels length 4.3-5.7 in SL. Snout 2.3-2.7, orbital diameter 5.7-6.9, and interorbital diameter 3.5-3.7 in HL. Dorsal-fin: i,5-i,6*; pectoralfin:i,8-i,9*; pelvic-fin: i,5; anal-fin: iii,7-iii, $8^{*}$-iv,7iv, $8^{*}$; caudal-fin: $(\mathrm{i}, 7+7, \mathrm{i}) *-(\mathrm{i}, 9+7, \mathrm{i})-(\mathrm{i}, 8+7, \mathrm{i})-$ $(\mathrm{i}, 7+8, \mathrm{i})$. Body varying from dark brown in small specimens to almost black in larger ones, with a transversal band at the end of the caudal peduncle and pale-yellow ventrally. Coloration upon capture on Figure 3. Morphometric data in Table 1.

Cetopsorhamdia iheringi (Fig. 1 and 3; Table 1) may be distinguished from $C$. boquillae, $C$. filamentosa, C. molinae, and C. phantasia by the length of its maxillary barbels that slightly surpass the origin of pectoral-fins (vs. reaching or surpassing the end of pectoral fins in C. boquillae, the base of pelvic fins in C. filamentosa and C. molinae, and extending beyond the base of anal-fin in C. phantasia).

The coloration pattern allows the distinction of $C$. iheringi from C. insidiosa, C. molinae, $C$. boquillae, C. phantasia, C. picklei, and C. nasus. In $C$. iheringi this consists of dark-brown body background, turning to pale yellow ventrally. Head dark-grey with pale lips. Five light blotches at dorsum, the first posterior to the supraoccipital, the second and third at dorsal-fin origin and end respectively, the fourth at posterior margin of adipose fin and the fifth at the caudal fin origin. Sometimes the dorsum is dark and blotches are not noticeable. This pattern is different from of $C$. insidiosa which has a relatively big golden-yellow spot on dorsal fin insertion and a dark brown band on the caudal-fin base; $C$. boquillae is distinguishable by a distinct yellow band around the head, a notorious yellow spot in front of first dorsal-fin ray and another at the end of it; C. phantasia pattern is characterized by the anterior part of the body iridescent green with snout, lips, and chin very dark and two ovate, light-colored spots on nape bracketing occipital process, body olive gray and basal portion of fins very dark, contrasting with distal tip almost unpigmented; C. molinae has a metalyellow body with four wide brown bands, first on predorsal, second at the end of dorsal fin base, third over the adipose-fin and fourth at caudal peduncle; C. picklei is characterized by the caudal fin white, sharply contrasting with blackish caudal-fin base; $C$. nasus has small purplish dots and a light band across the base of the occipital. 


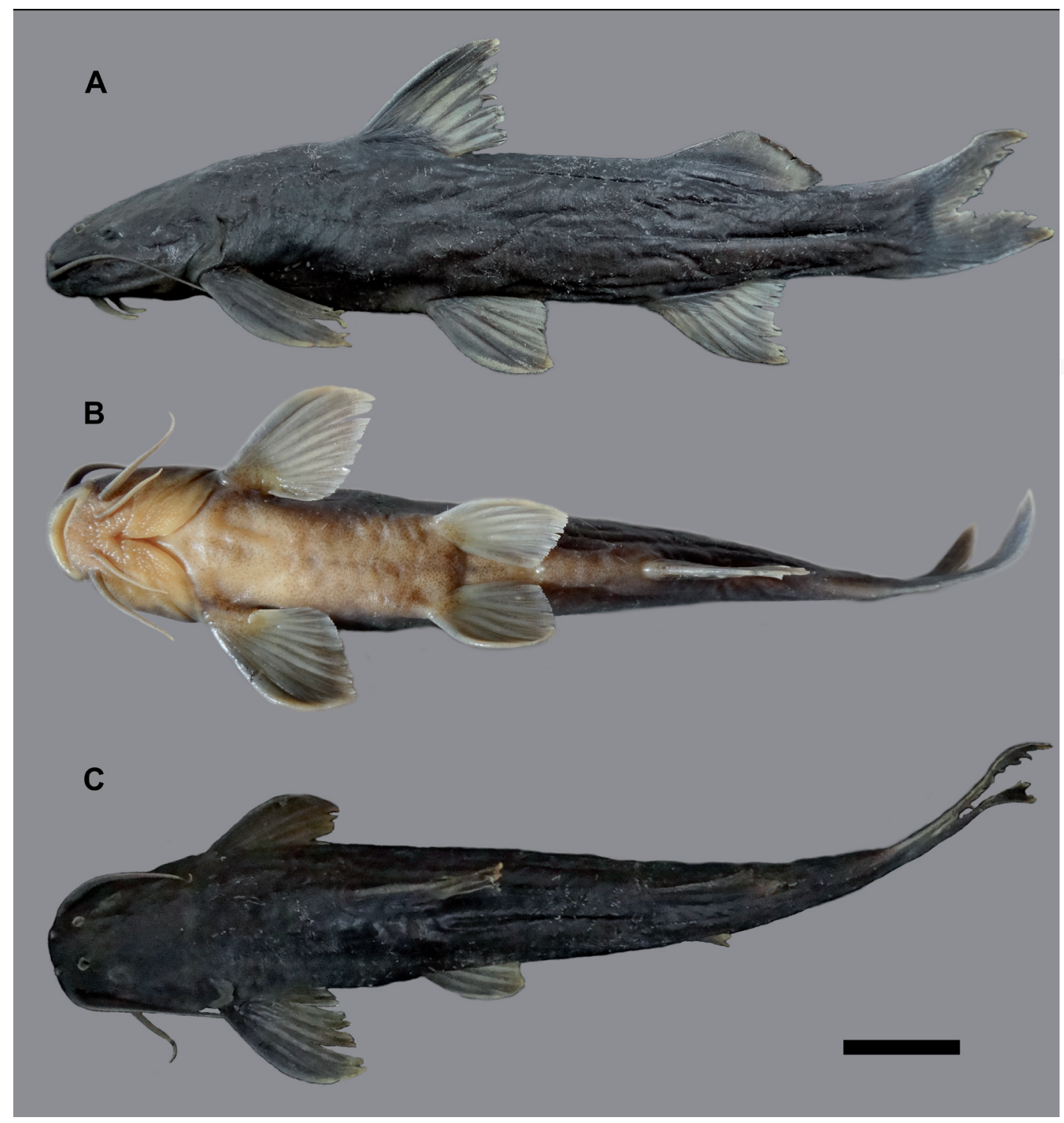

Fig. 1: Cetopsorhamdia iheringi from Tabay Stream, 69.85 mm, LGE-P 544.

Cetopsorhamdia orinoco differs from C. iheringi in morphometric characters, as body depth (14.2-14.8\% vs. $18.5-21 \%)$, body width (20.6-20.8\% vs. $17.5-19 \%)$, caudal peduncle depth $(23.6-24 \%$ vs. 17-21.7\%) and length of anal-fin base (22.6$24.3 \%$ vs. $14.7-17.5 \%$ ). Cetopsorhamdia iheringi can also be distinguished from $C$. molinae by the length of caudal peduncle longer in $C$. molinae (33\% vs. $17-21 \%)$.

The cranial fontanelle configuration distinguishes $C$. iheringi from C. insidiosa, C. filamentosa and C. boquillae (narrow fontanelles, the posterior one not reaching anteriorly the posterior margin of eyes vs. reaching that margin in $C$. insidiosa; wide and extending until anterior margin of the eyes in C. filamentosa, and extended and narrow with absence of epiphyseal bar in $C$. boquillae). Cetopsorhamdia iheringi also differs from $C$. phantasia by the number of dorsal-fin rays $(i, 6$ vs $i, 10)$ and the absence of contact with the dorsal skin of the neural spines of the five anterior vertebrae, as described for C. phantasia. 


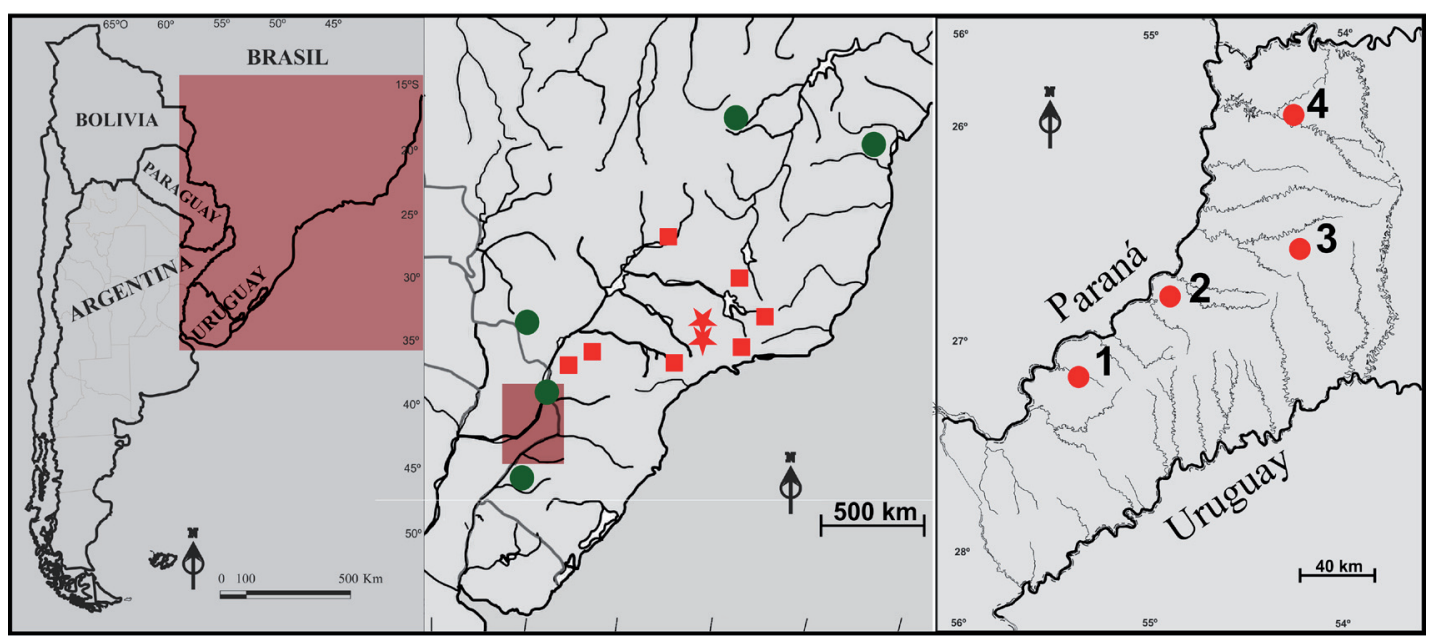

Fig. 2: Map showing the distribution of Cetopsorhamdia iheringi. Holotype and paratype localities (stars), points with published records (squares), records from collection database (circles) and new localities in Misiones, Argentina: (1) Tabay, (2) 3 de Mayo, (3) Isla and (4) Uruzú streams.

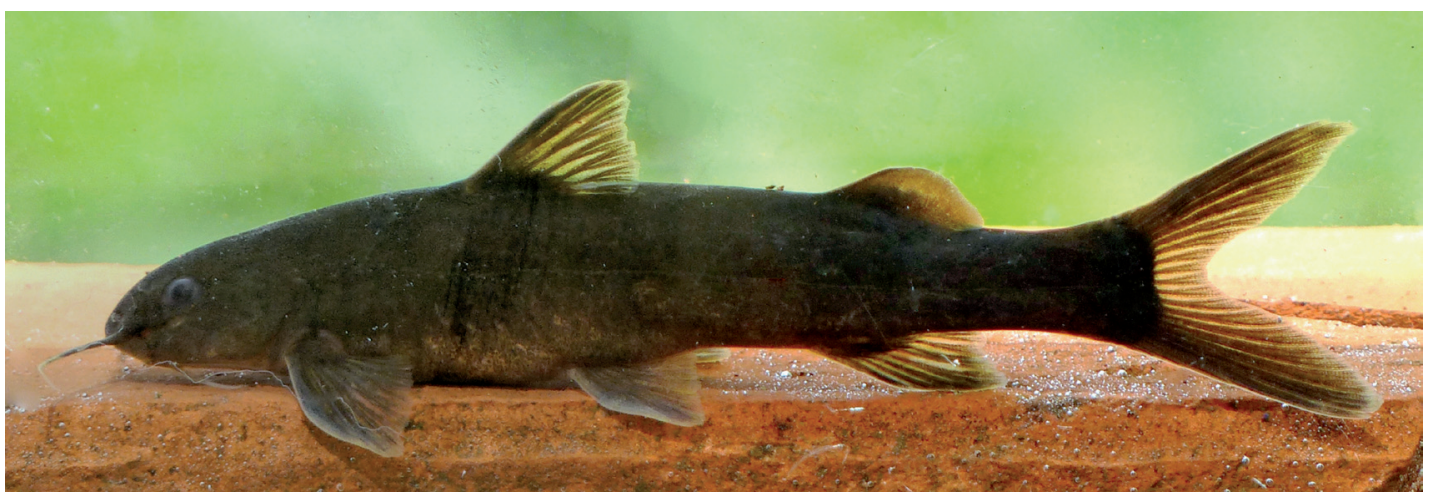

Fig. 3: Cetopsorhamdia iheringi $(70.8 \mathrm{~mm})$ from Tabay Stream; coloration upon capture.

Distributional notes: Figure 2 summarize distributional records of $C$. iheringi available in scientific publications (red squares), and some records from public collections of Brazil (green dots). According to the latter, some specimens identified as $C$. iheringi come from localities to the south of those given in published records. The closest point to the new records given herein are from Iguazú River at the city of Foz do Iguazú (MZUEL 15671), and from a tributary of the Paraná River at Marechal Candido Rondón (NUP 3664). Extreme distributional points of the species are given by vouchers stored at public collections of Brazil under the catalog numbers: MBML 11880 (North), MCP 00023187 (South), MCP 000036932 (East) and NUP 9348 (West).

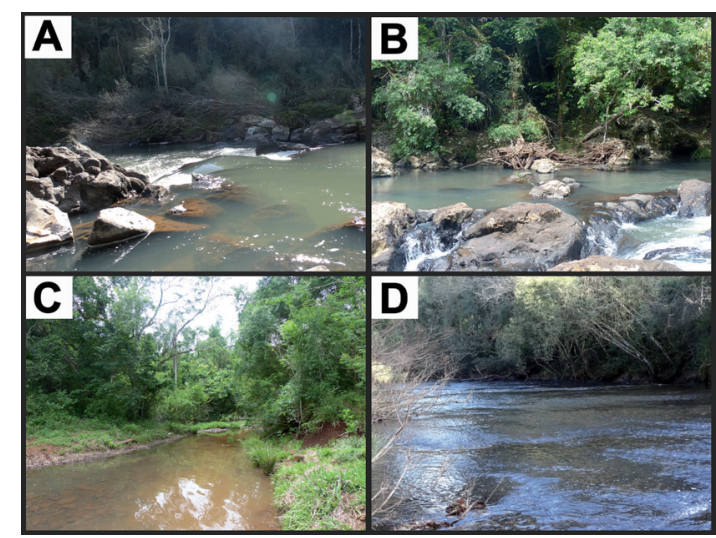

Fig. 4. Collection localities: (A) Tabay; (B) 3 de Mayo; (C) Isla; (D) Uruzú. 1 meter depth or less), with moderate to strong 1 meter depth or less), with moderate to strong
current, at four different streams, in particu-
Ecological notes: The specimens of $C$. iheringi were caught always at shallow areas (about 
Table 1: Morphometric data of Cetopsorhamdia iheringi(n=18). SL: standard length, HL: head length, SD: standard deviation.

\begin{tabular}{|c|c|c|c|}
\hline & Range & Mean & SD \\
\hline $\mathrm{SL}(\mathrm{mm})$ & $43.0-111.2$ & - & - \\
\hline \multicolumn{4}{|l|}{ Percents of SL } \\
\hline Head Length & $22.7-27.9$ & 25.5 & 1.4 \\
\hline Body depth & $17.5-24.4$ & 20.1 & 1.8 \\
\hline Body width & $17.5-20.2$ & 19.1 & 0.8 \\
\hline Predorsal distance & $36.7-43.0$ & 40.1 & 2.0 \\
\hline Prepectoral distance & $19.9-24.4$ & 22.4 & 1.4 \\
\hline Preventral distance & $42.0-46.1$ & 44.0 & 1.4 \\
\hline Preanal distance & $64.3-69.7$ & 66.9 & 1.3 \\
\hline Preadipose distance & $68.6-72.5$ & 70.6 & 1.4 \\
\hline Caudal peduncle length & $16.7-23.1$ & 19.3 & 2.1 \\
\hline Caudal peduncle depth & $9.9-11.6$ & 10.5 & 0.6 \\
\hline Dorsal-fin base length & $10.5-13.4$ & 11.9 & 0.8 \\
\hline Interdorsal distance & $17.8-23.6$ & 21.3 & 2.1 \\
\hline Adipose-fin base length & $14.7-18.8$ & 17.1 & 1.3 \\
\hline Anal-fin base length & $12.2-15.8$ & 13.8 & 0.9 \\
\hline Adipose depth & $2.8-6.8$ & 5.2 & 1.1 \\
\hline Length of first pectoral branched ray & $16.2-20.7$ & 18.7 & 1.1 \\
\hline Length of first ventral branched ray & $14.5-18.5$ & 16.1 & 1.2 \\
\hline Length of first anal branched ray & $12.2-20.0$ & 16.1 & 2.4 \\
\hline Length of first dorsal branched ray & $16.7-21.3$ & 18.7 & 1.4 \\
\hline \multicolumn{4}{|l|}{ Percents of HL } \\
\hline Eye diameter & 15.1-19.1 & 17.3 & 1.5 \\
\hline Snout length & $31.6-43.7$ & 38.3 & 3.4 \\
\hline Interorbital distance & $23.6-29.2$ & 26.2 & 1.7 \\
\hline Head width & $58.6-79.3$ & 72.4 & 5.4 \\
\hline Head depth & $52.1-61.3$ & 56.7 & 3.3 \\
\hline Maxillary barbell length & $64.7-102.0$ & 87.4 & 12.3 \\
\hline Outer mental barbell length & $43.1-63.5$ & 55.1 & 6.3 \\
\hline Inner mental barbell length & $33.6-50.2$ & 42.0 & 5.4 \\
\hline Eye to anterior nostril & $22.9-29.4$ & 26.9 & 2.3 \\
\hline snout to posterior nostril & $27.8-34.1$ & 30.6 & 2.1 \\
\hline inter-nostril & $16.5-20.5$ & 18.5 & 1.4 \\
\hline
\end{tabular}

lar areas that shared almost the same features (Fig. 4). The riverbed was mainly composed of basaltic bedrock with some loose stones.

Examined material: From Argentina: Misiones: Paraná River basin.

1) Tabay Stream, Jardín América,

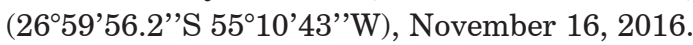
LGE-P 544: 4 ex (43-69.85 mm SL). CI-FML: 7242: 5 ex ( $1 \mathrm{c \& s})(43.0-70.8 \mathrm{~mm}$ SL). IBIGEO-I 355: 3 ex (47.6-63.2 mm SL). Coll.: G. Aguilera, F. Alonso, M. Benitez, M. Mirande and G. Terán.

2) 3 de Mayo Stream, (26 45'28,8'S $54^{\circ} 55^{\prime} 26,4^{\prime \prime}$ 'W), November 14, 2016. CI-FML 7243. 5 ex (1c\&s) (45.52-111.23 mm SL).Coll.: G. Aguilera,
F. Alonso, M. Benitez, M. Mirande and G. Terán. 3) Isla Stream $\left(26^{\circ} 36^{\prime} 22.7^{\prime \prime} \mathrm{S} 54^{\circ} 27^{\prime} 18.4^{\prime \prime} \mathrm{W}\right)$, November 15, 2016 . CI-FML 7244. 1 ex. (63.26 mm SL).Coll.: G. Aguilera, F. Alonso, M. Benitez, M. Mirande and G. Terán.

4) Uruzú Stream, Parque Provincial Urugua-í (2551'20.77'S 5410'01'W), July 06, 2017. LGE-P 701: 4 ex. Coll. M. Benitez and J. Boeris.

\section{DISCUSSION}

Cetopsorhamdia currently includes nine valid species that are mainly distributed at north and northeastern South-America. To date, Cetopsorhamdia iheringi is the species with the southernmost records and the only one present 
in the Rio de La Plata basin. In this contribution we add four new points to the distribution of $C$. iheringi in the Paraná River basin and also report for the first time its occurrence in Argentina and the Middle Paraná basin. The previous published southernmost record of this species corresponds to the Piquiri and Ivaí rivers both belonging to the Paraná River basin at the State of Paraná in Brazil (Delariva \& da Silva, 2013), so this paper represents a linear southward extension of 260 $\mathrm{km}$ from the known distribution of $C$. iheringi. However this distance might be overestimated if we take into account specimens records from public ichthyological collections. An exploratory searching on collection database of Brazil suggested that besides the distribution based on the literature, $C$. iheringi species might be present at the Uruguay River basin and the Rio das Contas basin, a costal drainage of northeastern Brazil. The record in the Iguazú River is from the stretch downstream the falls and considerably reduces the distance extension. However, the revision of that material lays beyond the object of this work. We presently just consider the published records as reliable to establish the distribution of the species.

This new record increase to seven the genera and to 20 the species of the family Heptapteridae currently known from Argentina, considering the most updated checklist of Argentinean ichthyofauna (Mirande \& Koerber, 2015; Koerber et al., 2016) and the recently described Heptapterus mandimbusu (Aguilera et al., 2017). The Convention on Biological Diversity (CBD) proposed that each country should have accurate and updated lists of fauna and flora (Reis et al., 2003). From this perspective, the record here in presented contributes with that recommendation and should be taken into account in managements and conservation programs in the region.

To date, the only diagnosis of Cetopsorhamdia iheringi is the one provided with its description by Schubart and Gomez (1959). They compared this species only with $C$. Insidiosa and C. miri$n i$, the latter currently classified as a species of genus Imparfinis. Thus, an exhaustive revision and a full diagnosis are needed for this species. Herein we provide a comparison of $C$. iheringi with all the species of the genus currently considered as valid. This comparison is based on the literature and we are aware of the need to corroborate this by the examination of the type material of $C$. iheringi. However, the situation of the type series is uncertain and the specimens are probably lost. Schubart and Gomez (1959) deposited the holotype and paratypes at "Estação Experimental de Biologia e Piscicultura" (E.E.B.P) in Piraçununga, Brazil, currently under management of the "Instituto Chico Mendes de Conservação da Biodiversidade". Upon our request, we were informed that the type series of $C$. iheringi is not physically located in that collection. According to our available information, the specimens were kept by Manoel Pereira de Godoy, the collector of the type series, and now the specimens would be under the care of his family.

\section{ACKNOWLEDGMENT}

We thank Diego Baldo and Juan Martin Ferro for field support. Pedro Sánchez from Fundación Miguel Lillo for logistical assistance. FONCyT (PICT 2011-0992 and 2012-2683; PIP 0301) for financial support. To Ministerio de Ecología y Recursos Naturales Renovables de la Provincia de Misiones for fishing permits. Fundación Miguel Lillo, Universidad Nacional de Misiones (UNaM) and Consejo Nacional de Investigaciones Científicas y Técnicas (CONICET) for constant support.

\section{REFERENCES}

Aguilera, G., M. Benitez, G.E. Terán, F. Alonso \& J.M. Mirande. 2017. A new species of Heptapterus (Siluriformes, Heptapteridae) from the Uruguay River Basin in Misiones, Northeastern Argentina. Zootaxa 4299 (4): 572-580.

Bockmann, F.A. \& G.M. Guazzelli. 2003. Family Heptapteridae (Heptapterids). Pp. 406-431 in: Reis, E., S.O. Kullander \& C.J. Ferraris Jr. Checklist of the freshwater fishes of South and Central America. Porto Alegre: EDIPUCRS.729 pp.

Casatti, L. \& R.M. Castro. 1998. A fish community of the São Francisco River headwaters riffles, southeastern Brazil. Ichthyological Exploration of Freshwaters 9: 229-242.

Casarim, R., M. Lopes Bueno \& P. Santos Pompeu. 2012. Ichthyofauna of the Aiurouca River basin, Minas Gerais, Brazil. Check List 8(6): 1166-1171.

Cetra, M., W. Barrella, F.L. Neto, A.G. Martins, B.J. Mello \& R.S. Almeida. 2012. Fish fauna of headwater streams that cross the Atlantic Forest of south São Paulo state. Check List 8(3): 421-425.

Cunico, A.M., W.J. da Graça, A.A. Agostinho, W.M. Domingues \& J.D. Latini. 2009. Fish, Maringá urban streams, Pirapó river drainage, upper Paraná river basin, Paraná State, Brazil. Check List 5(2): 273-280.

da Graça, W.J. \& C.S. Pavanelli. 2007. Peixes da planície de inundação do alto rio Paraná e áreas adjacentes. 
Maringá: EDUEM. 241 pp.

Delariva, R.L. \& J.C. da Silva. 2013. Fish fauna of headwater streams of Perobas Biological Reserve, a conservation unit in the Atlantic Forest of the Northwestern Paraná State, Brazil. Check List 9(3): 549-554.

Eigenmann, C.H. 1916. New and rare fishes from South American rivers. Annals of the Carnegie Museum 10(6): 77-86, Pls. 13-16.

Eigenmann, C.H. 1922. The fishes of western South America. Part I. The fresh-water fishes of northwestern South America, including Colombia, Panama, and the Pacific slopes of Ecuador and Peru, together with an appendix upon the fishes of the Rio Meta in Colombia. Memoirs of the Carnegie Museum 9(1): 1-346.

Eschmeyer, W.N., R. Fricke \& R. van der Laan (eds). Catalog of fishes: genera, species, references. Electronic version http://researcharchive.calacademy.org/research/ichthyology/catalog/fishcatmain. asp. Accessed: April 15, 2017.

Ferraris, C.J. 2007. Checklist of catfishes, recent and fossil (Osteichthyes: Siluriformes), and catalogue of siluriform primary types. Zootaxa 1418: 1-628.

Fowler, H.W. 1945. Descriptions of seven new freshwater fishes from Peru. Notulae Naturae, Academy of Natural Sciences of Philadelphia 159: 1-11.

Ingenito, L.F. \& P.A. Buckup. 2007. The Serra da Mantiqueira, south eastern Brazil, as a biogeographical barrier for fishes. Journal of Biogeography 34(7): 1173-1182.

Koerber, S., T.O. Litz \& J.M. Mirande. 2017. CLOFFARupdate 3 -supplement to Checklist of the Freshwater Fishes of Argentina. Ichthyological Contributions of Peces Criollos, 47: 1-9.

Lundberg, J.G. \& L. McDade. 1986. A redescription of the rare Venezuelan catfish Brachyrhamdia imitator Myers (Siluriformes: Pimelodidae) with phylo- genetic evidence for a large intrafamilial lineage. Notulae Naturae, Academy of Natural Sciences of Philadelphia 463: 1-24.

Mirande, J.M. \& S. Koerber. 2015. Checklist of the freshwater fishes of Argentina (CLOFFAR). Ichthyological Contributions of Peces Criollos 36: $1-68$.

Ortega-Lara, A. 2012. Redescripción de Cetopsorhamdia nasus Eigenmann y Fisher, 1916 (Siluriformes: Heptapteridae). Biota Colombiana 13(1): 47-70.

Pavanelli, C.S., W.J. da Graça, C.H. Zawadzki, H.A. Britski, A.P. Vidotti, G.S. Avelino \& S. Veríssimo. 2007. Fishes from the Corumbá Reservoir, Paranaíba River drainage, upper Paraná River basin, State of Goiás, Brazil. Check List 3(1): 58-64.

Reis, R.E., S.O. Kullander \& C.J. Ferraris (Eds.). 2003. Checklist of the freshwater fishes of South and Central America. Porto Alegre: EDIPUCRS. 729 pp.

Ruiz-C, R.I. \& C. Román-Valencia. 2006. Aspectos taxonómicos de Cetopsorhamdia boquillae y C. nasus (Pisces, Heptapteridae), con anotaciones sobre su ecología en la cuenca alta de los ríos Magdalena y Cauca, Colombia. Animal Biodiversity and Conservation 29(2): 123-131.

Schubart, O. \& A.L. Gomes. 1959. Descrição de Cetopsorhamdia iheringi sp. n. (Pisces, Nematognathi, Pimelodidae, Luciopimelodinae). Revista Brasileira de Biologia 19: 1-7.

Schultz, L.P. 1944. The catfishes of Venezuela, with descriptions of thirty-eight new forms. Proceedings of the United States National Museum 94: 173-338.

Species Link. Available at http://www.splink.org.br. Retrieved at Jul 12, 2017.

Stewart, D.J. 1985. A new species of Cetopsorhamdia (Pisces: Pimelodidae) from the Río Napo basin of eastern Ecuador. Copeia 2: 339-344.

Doi: 10.22179/REVMACN.19.507

Recibido: 28-IV-2017

Aceptado: 26-IX-2017 
